\title{
FUNGSI PEMARKAH WACANA: SEBUAH KASUS DI KELAS BERBICARA PADA LEVEL UNIVERSITAS
}

\author{
Afrianto dan Arlez Restika \\ Faculty of Arts and Education, Universitas Teknokrat Indonesia \\ email: afrianto@teknokrat.ac.id
}

\begin{abstract}
Abstrak
Penelitian ini menginvestigasi fungsi pemarkah wacana dan pengetahuan mahasiswa mengenai pemarkah tersebut. Penelitian ini adalah penelitian kualitatif. Data dikumpulkan melalui video-recording dan transkripsi. Analisis data menggunakan teori Brinton dan Alami. Penelitian ini menemukan seluruh jenis fungsi tekstual, yaitu sequence, repair, opening and closing frame markers, filler, information indicator, topic switcher, dan turn taker. Namun, fungsi interpersonal jarang ditemukan karena pembicara hanya berfokus pada penyampaian materi. Lebih jauh dapat dikatakan bahwa pembicara memiliki keterbatasan pengetahuan mengenai pemarkah wacana sehingga kerap menggunakan pemarkah yang sama. Oleh karena itu, penelitian ini menyarankan dosen untuk memperhatikan masalah ini dan menjadikan ini sebagai salah satu butir dalam penilaian.
\end{abstract}

Kata Kunci: pemarkah wacana, fungsi tekstual dan interpersonal

\section{FUNCTIONS OF DISCOURSE MARKERS: A CASE STUDY OF A SPEAKING CLASS AT TERTIARY EDUCATION}

\begin{abstract}
This study aimed to investigate functions of and students' familiarity with discourse markers. This was a qualitative study. The data were collected through video-recording and transcription. The data analysis used Brinton's and Alami's theories. The study revealed all textual functions, i.e.: sequence, repair, opening and closing frame markers, filler, information indicator, topic switcher, and turn taker. The interpersonal function was almost never found because the speaker only focused on delivering materials. Further, it was noted that the speaker had limited knowledge of discourse markers so that the same discourse markers were often used. The study thus suggested the lecturer should take these into account in the assessment.
\end{abstract}

Keywords: discourse markers, textual and interpersonal functions

70 | LITERA Volume 17, Nomor 1, Maret 2018 


\section{INTRODUCTION}

Linking words or sentences is what discourse marker functions. Further, discourse markers also indicate a speaker's attitude to what speaker is saying (Ismail, 2012:2). Written or spoken text is where the discourse markers appear from. Schiffrin in Rido (2010) says that it is important to understand discourse markers since they are parts of discourse coherence and cohesive devices such as to integrate forms, meaning, and action to make overall senses out of what is said. Furthermore, Fraser (1996) states that discourse markers help the speaker to clarify the relationship the speaker intends to convey between two segments. It contributes to the interpretation of massage. Thus, this research investigated discourse marker especially used in a presentation conducted by a student, and then it focused on the function of the discourse marker itself. Further, this research was intentionally designed to deeply understand the phenomena of the usage and student's familiarity of discourse markers. Here is an example taken from a student's presentation. This presentation was recorded on April 2016 in Teknokrat when the student took the examination of speaking skill for tour guide.

Good morning ladies and gentleman, thank you for the chance given to me and I am so glad to meet you today. First of all, let me introduce myself, my name is Arlez Restika as tour guide and today I would like to guide you in exploring the tourism in Turkey. First, you go by plane from SoekarnoHatta international airport to Ataturk international airport of Turkey and it takes time for about 12 hours 15 minutes.
It is noted that there are three discourse makers found, they are Good morning ladies and gentleman, first of all and first. The first discourse marker (Good morning ladies and gentleman) initiates the greeting to open the presentation. Then, the second one is first of all, it functions to show the order of the points spoken and it indicates the first point. The following marker found is not too different from the previous one, it is first. It refers to the sequence indication, in which the first thing that visitors should do to visit Turkey is taking off by the plane. Further, from the example there is also a marker of cohesion used to connect two clauses by providing further information toward the previous one. It is and. Hence, each marker used in the presentation has its own function. This is the thing that this research tried to find out, further it also was aimed at probing any possibilities of finding a marker which has more than one function in a discourse. Discourse thus refers to pieces of language larger than a sentence that function together to convey a given idea or information.

Regarding the example above, it can be stated that discourse marker plays an important role to help the listener understand what speaker or writer means. Along with it, Sharndama and Yakubu (2013) define a marker as the linguistic device used to hang pieces of discourse together. It is used in conversation and writing to show or link ideas or information in a particular context. Furthermore, Swan (2005) posits discourse markers as words or expressions showing the connection between what the speaker said and the context. Analogically, the discourse marker plays as a bridge connecting islands or 
cities of a country. In this case, island or cities refer to utterances/expressions/sentences, and then a country construes a discourse. According to Schiffrin (1987: 49), discourse markers are parts of the more general of discourse coherence. Without sufficient discourse markers, the information will not seem logically constructed and the connections between previous and next sentences will not be obvious. Here is another example taken from Feng (2010).

How to improve our English? Don't think the English is just a matter of grammar and vocabulary. [Because] Listening, reading, writing and speaking are [also] the key to learn English well. Listening frequently to special programs will help us improve our listening comprehension. [And] You can watch English and American Film to train your hearing. [And] Watch movies also can train you words' pronunciation.

It is noted that those sentences are grammatically correct but if the discourse markers in the brackets are added, the sentences would read more naturally and be related each other. Further, if it is related to writing or speaking class, students sometimes do not use discourse markers. It is purposively to avoid the unpredicted mistakes because of unfamiliarity. This unfamiliarity deals with the idea how to use it correctly. This situation thus makes the presentation and the writing a bit unnatural. They even sometimes use discourse markers in an improper context, so the utterances or sentences are not wellorganized. Simply, it sometimes problematizes students in their presentation and writing. Going from such a phenomenon, this research was conducted. Specifically, this research was designed in a speaking class of the English Literature Study Program of Universitas Teknokrat Indonesia, Lampung. Since the class consisted of 25 students, this research made the criteria to choose a student. The criteria are GPA (Grade Point Average) should be more than 3.5; being active in any campus events; getting award or winning any English competitions; and lecturer's recommendation. Those criteria then led the research to find a student.

Regarding the lecturer's recommendation, this research would go along with a presentation dealing with a fiction book report; it is one of the agenda (based on the learning contract). Fiction book report requires the students to present their review toward a novel. The presentation will be in 15 to 20 minutes covering two sessions; explanation and question and answer sections. Thus, this research focused on the explanation section only. As further information, this research engaged discourse analysis as the approach.

Discourse analysis is sometimes defined as the analysis of language beyond the sentences. Zellig Harris, an American 1inguist who first used the term of discourse in 1952 to refer to the analysis of connected speech or writing. Connected discourse occurs within a particular situation whether of a person speaking, or of a conversation, or of someone sitting down occasionally over the period of months to write a particular literary or scientific tradition. (Harris, 1952 as cited by Meyerhoff, 2012: 2).

Thus, according to Harris (1952) as cited by Meyerhoff (2012:2) there are typical ways of using language in particular situations. He posits that they do not only contain a certain meaning but they can 
also be characterized based on linguistic features associated with them. The meaning and the features are the central interest of discourse analysis. Accordingly, one of discussion in discourse analysis is discourse marker. The following part would provide a discussion of discourse markers.

Linguistic devices that are used to hang the pieces of language or expression together are called discourse markers. They are used in spoken or written text to show the relationship among ideas or information in a particular context and it can be in form of word or phrase. For example so, right, moreover, um, oh, etc. Giving a naturalistic conversational effect and helping the hearers in understanding what speaker says are what discourse markers can do.

Further, Lenk (1997:4) as cited by Fritz (2007: 4) defines discourse marker as a short lexical item associated with a pragmatic meaning on a multilingual level of discourse, further it is used to signal the hearer how the speaker intends the current contribution related to preceding and/ or following parts of the discourse. It means that discourse marker is one of crucial parts in communication and it helps the hearers or readers catch up the preceding and following information given by speaker. Discourse marker also helps the speaker how to signal the information to the hearer, so that speaker and hearer have the same assumption.

Brinton (1996) as cited by Alami (2015) proposes the definition of discourse markers as phonologically short items that have no or little referential meaning but serve pragmatic or procedural purpose. Therefore, discourse markers help the listeners to interpret what speaker says. She also proposes the characteristics of discourse markers, such as: frequently appearing in oral discourse as a sufficient condition as impromptu; occurring in sentences initially, medially, and finally; having little or no prepositional meaning or at least to be difficult to specify lexically; and occurring outside the syntactic structure or loosely attached to it. In other words, they have no clear grammatical function and seem to be optional rather than obligatory features. Further, Yule (1983: 106) as cited by Brinton (1996: 34) notes discourse markers represent optional cues which writers or speakers may use to organize what they want to communicate. It means discourse markers bridge ideas one to another delivered by the speaker or writer. It is also posited by Fraser (1998:22) as cited also by Brinton that the absence of discourse markers does not render a sentence ungrammatical and/or unintelligible but does remove a powerful clue.

In another discussion dealing with the lecture discourse, Chaudron and Richards (1986) as cited by Fortuno (2006) define the type of discourse markers into two i.e. micro markers (lower-order discourse markers) and macro markers (higher-order discourse markers). Micro markers are used as links to signal the internal or ideational relations within sentences so the relations of one clause to another clause or one sentence to another sentence are easier to comprehend (Rido, 2010:2). Further, they function as fillers and they fill pauses giving listeners more time to process individual segments of a piece of discourse. Meanwhile macro markers are essentially used to signal the transition or the moves from one phase of a lecture to another phase, to indicate a shifting of 
one topic to another topic, and to organize the lecture structurally so that students are clear about the subject matters (Rido, 2010: 2).

Discourse markers have a number of different functions depending on the context. For example, it is used to signal the relationship of an utterance to the immediate context with the primary function to draw the listener's attention to a transition or a break in conversational routine. In addition, Brinton presents an inventory of ten functions which she group into two main categories. First, textual function which is related to the way the speaker structures meaning as text, creating cohesive passage of discourse, using language in a way that is relevant to the context (Brinton, 1996:35-40 as cited by Alami, 2015:6). And second, interpersonal function which refers to the nature of the social exchange, that is, the role of the speaker and the role assigned to the hearer (Brinton, 1996:35-40 as cited by Alami, 2015:6).

In textual function, Brinton divided it into eight functions. They are:

1. Opening frame marker is to initiate discourse, including the attention of the hearer.

2. Closing frame marker is to close the discourse.

3. Turn-taker is to aid the speaker in acquiring or relinquishing the floor.

4. Filler is to serve as a filler or delaying tactic used to sustain discourse or hold the floor.

5. Topic switch is to indicate a new topic or partial shift in topic.

6. Information indicator to donate either new or old information.

7. Sequence/relevance marker is to mark sequential dependence.

8. Repair markers is to repair one's or others' discourse.

Interpersonal function deals with the addressor and addressee role, that is, the social exchange. Brinton divided interpersonal function into two, such as:

1. Subjectivity to express a response or reaction to the preceding discourse including also back-channel signals of understanding and continued attention while another speaker is having his/her turn.

2. Interpersonally to achieve intimacy between speaker and addressee. Further, it function to effect cooperation or sharing, including confirming shared assumptions, checking or expressing understanding, requesting confirmation, expressing difference or saving face (politeness).

\section{METHOD}

This research was conducted by applying qualitative method. It was because this type of study was based on data expressed mostly in the form of words rather than on number (William, 2011:130). The researchers video-recorded in a real class and collected the data from the transcription of the fiction book report presentation. It was an individual presentation, in which the student had to report/ present the review of a fiction book/novel. Thus, this study was deeply aimed at investigating an individual qualitatively. It is in line with Croker (2009); he says that the characteristic of qualitative method is exploratory with the goal to uncover new ideas and insights and to interpretatively analyze to figure out pattern of behavior 
and thinking. There was only one presentation recorded and it was taken from one of the students of speaking class. This student met with the criteria of the subject. Analyzing the data, the writer employed Brinton's and Alami's theory covering two types of functions; they are textual and interpersonal function. Both would be framed from the data. Further, to figure out the student's familiarity, this research would not determine from both types of function, but it would capture the familiarity from markers employed by the student.

The data source of this research was the transcription which was taken from oral fiction book report in speaking class. And the data of this research were in forms of words and phrases.

\section{FINDINGS AND DISCUSSION FINDINGS}

Regarding the objectives, the writer found textual and interpersonal functions. Textual functions of discourse markers are more related to the contraction of the discourse coherence, while the interpersonal functions of discourse markers are precisely more related to the reactions, responses, and relations built by the participants during the interaction, that is, the role of the speaker and hearer in the presentation. During the analysis, there are four initial letters used in the table, they are 'S' (Speaker); 'A' (Audience); 'L' (Line); and 'P' (Participants).

\section{Excerpt 1}

\begin{tabular}{lll}
\hline $\mathbf{L}$ & $\mathbf{P}$ & Utterances \\
\hline 1 & S & Assalamualaikumwarohmatullahiwabarohaktu/ \\
2 & A & Waalaikumsalamwarohmatullahiwabarokatu/ \\
3 & S & Okay $\downarrow$. Before we go further about. u:m my book \\
4 & & report, entitled the authentic story of Pinocchio of \\
5 & & Tuscany by Carlo Collo- +Collodi, maybe I wanna \\
6 & & ask one of you. Maybe miss Dena..u:m. \\
\hline
\end{tabular}

The word "okay" in line three is used by speaker in order to initiate the discourse and to attract the attention from the hearer. This marker is used intentionally in order to persuade the audience to take a part in this presentation. Then, "Before we go further about" is used as the starter of the discourse. Further, the speaker used a couple of fillers such as " $u: m$ " in line three and six as delaying tactic to hold the floor. Those markers occurred unintentionally. In line three, the speaker tried to remember the title of book report. While the speaker was recalling the memory, the speaker deliberately uttered " $u ; m$ " and it also happened in line 6 . The speaker tried to think about the question that will be asked to the audience. The word "maybe" in line five included into interpersonal function which is used to check the understanding of the audience about the topic which will be discussed. While "maybe" in line six functions as turn taker, in which the speaker gave the chance to audience to share something they know about Pinocchio before the speaker continued discussing it further. It is in order to have response from the audience.

\section{Excerpt 2}

\begin{tabular}{lll}
\hline $\mathbf{L}$ & $\mathbf{P}$ & Utterances \\
\hline 7 & $\mathrm{~S}$ & what is the first thing, that come to your mind, about \\
8 & & Pinocchio $\uparrow$ \\
9 & A & $/ /$ yes// \\
10 & & Nose \\
11 & S & nose $\uparrow$ Just it $\uparrow$ \\
12 & A & $(($ no $))$ lie \\
13 & S & $/ /$ okay// \\
\hline
\end{tabular}

The audience used 'yes' to express a response toward the speaker's question. It is included in interpersonal function. Then, the speaker used 'just it' with rising intonation. It is in order to invite more audien- 
ces to give more comments. Further, another marker is also found, it is 'okay'. It is used to express a reaction or to respond audience's answer, it is also signalling the agreement.

\section{Excerpt 3}

\begin{tabular}{lll}
\hline L & P & Utterances \\
\hline 20 & S & so ladies and gentlemen, in THIS quotation, we -- \\
21 & & we know that the implicit meaning about -- about the \\
22 & & quotation itself/ it means that, u:m from one \\
23 & & generation to other --another generation, the \\
24 & & Pinocchio story, always give the good moral message \\
25 & & for -- especially for children, about do not tell lie, \\
26 & & and then do not trust with stranger easily, \\
\hline
\end{tabular}

In excerpt three, there are five discourse markers found. They are 'so ladies and gentlemen', 'it means that', 'u:m', 'especially', and 'and then'. They are included into macro marker. To start the discourse and give the summary from the previous information, 'so ladies and gentlemen' was used. Then, in order to repair the discourse and to make previous information clearer, 'it means that' is used. It is noted that the marker 'especially' is used to emphasize moral message given in $\mathrm{Pi}$ nocchio story to the children. The last marker found is 'and then' which was used to indicate the continuity of the message; i.e. do not tell lie and do not trust stranger easily. Whereas, the marker 'u:m' is used to fill an empty between two ideas (fillers).

\section{Excerpt 4}

\begin{tabular}{lll}
\hline $\mathbf{L}$ & $\mathbf{P}$ & Utterances \\
\hline 33 & S & So, pino that - we believe that, there is no. u:m. \\
34 & & there there is no -- ((what) $)$-- there is no someone \\
35 & & that, $\mathbf{u}: \mathbf{m}$ you can know from Pinocchio story, there \\
36 & & are so many kinds of moral message in- +inside it/ \\
\hline
\end{tabular}

In excerpt 4 , the speaker emphasized and strengthened the important information in the discourse by using meta-state- ment macro marker. There is an expression 'we believe that' used by speaker. It aimed to emphasize and strengthen important information in the discourse which related to moral message inside the story. Then, the marker ' $\mathrm{u}: \mathrm{m}$ ' as also found in lines 33 and 35 was employed to have delaying tactic and to hold the floor.

\section{Excerpt 5}

\begin{tabular}{lll}
\hline $\mathbf{L}$ & $\mathbf{P}$ & Utterances \\
\hline 65 & S & okay $\uparrow$, and the next (()) physical description in this \\
66 & & - - in this book, the author of this book is Carlo \\
67 & & Collodi, and then the title is the authentic story of \\
68 & & Pinocchio of Tuscany $\uparrow$. and then the year two \\
69 & thousand, publisher Jerry Cross and Pauline \\
70 & Bondonno Cross, Italy. \\
71 & And then this book contains of one hundred forty \\
72 & three pages, and the genre is fantasy, \\
73 & Because $\mathbf{u}: \mathbf{m}$ the writer -- after the - af- +after read \\
74 & this book, especially. Pinocchio itself is fantasy \\
\hline
\end{tabular}

Further, it can be reported that the same function found from the word "okay" in excerpt 5 (line 65). Uttered with rising intonation, it functions as the starter of discourse. Further, this marker was used to get the attention from the audience and also to check whether or not the audiences still pay attention to the speaker. It means that it is used intentionally by the speaker. In addition, to begin the new information, "and the next" is used. In addition, it is noted that the marker "And then" was found three times in lines $65,67,68,71$. Then, the marker "and" was also found in line 72 . Both are used to signal the continuity of information (the additional information). At another time, the speaker also used "because" to show causal marker in which speaker tried providing reason why the story has fantasy genre. Thus, "because" is used to signal the reason from the speaker. 


\section{Excerpt 6}

\begin{tabular}{lll}
\hline L & P & Utterances \\
104 & S & Okay, e:m about $\{$ NS $\}$ e:m extrinsic element in this \\
106 & & Pinocchio's -- Pinocchio book, the theme is - e: the \\
107 & theme of the story about end lasting love/ \\
108 & Why I choose. the theme is end lasting love, because \\
109 & I don't choose. do not tell lie, and then e:m do not \\
110 & trust to stranger easily $\{$ NS $\}$, because I think that.. \\
111 & everlasting love is the story, when gepetto really love \\
112 & pinocchio, and the lasting love. u:m even pinocchio \\
113 & tell lie, and then even pinocchio become naughty \\
114 & boy, so Gepetto really love. and always take of -- take \\
115 & of him/ \\
116 & So I choose that the theme is everlasting love, \\
117 & become, the theme of this story/ \\
118 & and then, about the character and characterization, \\
119 & the first one is, major character/ \\
120 & The first $\uparrow$ protagonist character is Pinocchio. \\
121 & So, why.. Pinocchio become the the major \\
122 & protagonist character, because u:m Pinocchio $\uparrow$ as the \\
123 & main character, in all of -- all of the story, or the sub - \\
124 & the subtitle in the story itself/ \\
125 & So, I believe that, Pinocchio hav- +have protagonist \\
126 & character, and it can be seen, from the $\{$ CG\} -- it can \\
127 & be seen from the, quotation inside the story, "but I am \\
128 & different from the other boys! I am -- the \\
129 & best boy in the world, and I $\uparrow$ always tell the truth/ \\
130 & I promise you, papa $\uparrow$. I will be - \\
131 & I will be very nice to you and \\
& I will take good care of you"/ \\
&
\end{tabular}

It seemed that every time the marker 'okay' (line 104) was produced by the speaker and it was mostly used to start a new discussion. It was noted that this marker was uttered ten times during the report presentation. Another thing found is fillers, such as u:m, e:m, and e. They can be found in lines 104, 105, 108, 111, and 121 . These fillers were produced to fill a momentary hesitation and to hold the floor. Further, the marker 'because' in lines 107, 109 and 121 indicate cause and effect relation of why the speaker finally decided end lasting love as the theme of the fiction book. The speaker strengthened her statement by adding marker 'because'. The following finding is the marker 'and then' in lines 108,112 , and 117. It is the connector linking for the additional infor- mation of the discourse. For instance in line 108 , the speaker used 'and then' to give more information; while in line 117, it was used to switch the discussion from talking about theme to character and characterization.

It is further noted that the markers 'the first one' (in line 118) and 'the first' (in line 119) were used to initiate any entity which is mentioned as the points discussed. Simply, it functions as the starter. The next marker found in lines 1120 and 124 is 'so'. Contextually, it was used to conclude and end up the discussion. In addition, the marker 'and' is found in lines 111 and 125 . Hence, it has the same function as discussed before that it indicated additional or further information for the previous one. Besides, the marker 'or' also appears, it clear that this marker functions as the indication of another/other alternative choices.

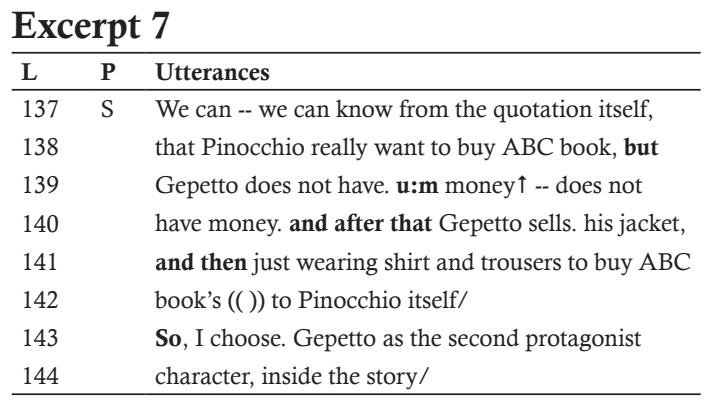

So far, the markers found in the excerpt 7 have the same function. For instance, the filler ' $u$ :m' function as the delaying tactic; the markers 'and after that' and 'and then' indicates the sequences of information or story; and the marker 'so' is used to indicate the end of the discussion which in form of conclusion. Further, another marker is also found; it is 'but'. Considering the context of the sentence, it clear that the marker 'but' was 
used to bridge the contrastive or opposite idea. It can be seen in lines 138-139. Accordingly, Pinocchio really wanted to have the book whereas Gepetto did not have money. It can reported from the finding that the marker 'but' links clauses in a sentence.

\section{Excerpt 8}

\begin{tabular}{lll}
\hline L & P & Utterances \\
\hline 249 & S & In conclusion, Pinocchio was one of fiction story, \\
250 & & which WRITTEN with the purpose or \\
251 & & sociali- socialai- + socializing children to meet $\{$ NS $\}$ \\
252 & & definite normative, expectation at home \\
253 & & and in the society/ \\
254 & & So moral - moral lesson, we can get from Pinocchio \\
255 & & story, do not tell lie, \\
256 & & and about the lasting love, $\{$ NS $\}$ because it is - u:m \\
257 & & -- do not to lie, it is not good, and it will only lead \\
258 & you to some serious problem/ \\
\hline
\end{tabular}

This discourse marker, "in conclusion" in line 249, is included into macro markers that can help the audiences to recall and retain the presentation. "Or" in line 250 and "and" markers in 253 function as the connector between the clauses. "Or" is used to connect the clause Pinocchio was one of fiction story, which written with the purpose expectation at home and in the society to the next clause socializing children to meet definite normative.

After concluding Pinocchio as a fiction story, the speaker delivered moral message. To initiate it, the speaker used "so" in line 254. "because" in line 256 is used to indicate relational reason. It can be seen from these clauses, moral lesson, we can get from Pinocchio story, do not tell lie, and about the lasting love, because it is $-u: m$ -- do not to lie, it is not good, and it will only lead you to some serious problem. Completely, the speaker would like to explain that the fiction book presented teaches the readers to tell the truth whatever the condition is.
Thus, there will be bad consequence coming to us, for example in this story, whenever Pinocchio is telling lie, his nose will grow abnormally.

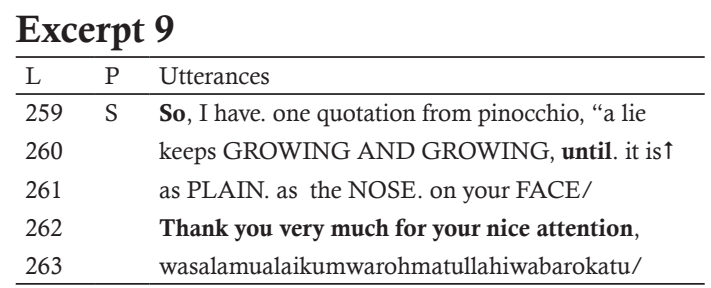

After delivering the report in front of the class, the speaker should sum up the presentation. The speaker gave the conclusion by illustrating it through the quotation. That quotation illustrates the moral message from Pinocchio's story. To indicate the conclusion, the speaker used "so" in line 259. This marker was uttered intentionally in order to make the audiences always remember moral message that can be taken from the story. While the marker "until" functions as the connector between the clauses of message $\underline{a}$ lie keeps GROWING AND GROWING to following clause it is ${ }^{\uparrow}$ as PLAIN. as the NOSE. on your FACE. Then, the speaker closed the presentation by using discourse marker Thank you very much for your nice attention. It was delivered in order to say thank you to the audience for paying attention and participating during the presentation of fiction book report presentation.

\section{DISCUSSION}

Through the results, it is noted there are 26 kinds of marker found and those markers have their own function. The type of function a marker has depends on the context of the discourse. Those markers are okay, maybe, actually, before we go further, 
u:m, yes, just it, Ladies and Gentlemen, especially, and then, we believe that, I believe that, and the next, because, the first, the first one, the second one, and fourth, so, but, in conclusion, or, until, thank you very much for your nice attention, it means that. There are three functions of markers which are produced most frequently. They are sequence marker, filler, and information indicator. They are presented in this part.

It can be reported that as the most frequent one, the sequence marker was used to signify the continuity of points discussed. It seemed so because the students presented some points of report. On another extent, Asik and Cephe (2013) found the same thing. They figured out that this type of marker was most frequently used by the native students. Furthermore, the second marker which appeared most frequently after sequence marker is filler, in form of $u: m$ and $e$. It was used often to hold the floor and to fill empty among ideas. This current research also figured out that the student produced this marker to recall information stored in the memory. It means that sometimes it is produced unconsciously by the student. Another function of this filler is that it is a strategy to delay the presentation because of memorizing materials. In addition, Castro (2009) captured this phenomenon from a research of a class interaction investigation. She found that students so often produced fillers, such as um/e, yeah, mhm. Further, Asik and Cephe (2013) found um produced by the native student while the non-native students produced uhh. It means that there are some alternative markers functioning as filler, they are $u: m$. umm, $e:, m h m$, and uhh.

Another function which has number of times of occurrence is information indicator. The markers functioning information indicator are the first, the first one, the second one, the third one, and fourth, the last. They were used to indicate entities of information mentioned as the point discussed from the earliest and the latest point.

There is an interesting marker discussed in this part, i.e. okay. This current research came to a conclusion that this marker has more than one function depending on context. For instance; Okay produced in a raising intonation indicates a start of a discourse or initiation of a talk. Another point is that this marker was used also to respond audience's answer. In addition, in a class interaction, Thornbury and Slade (2006) argue that the markers (right? and $O k$ ?) can signal a response elicitors.

Regarding the frequent marker used by the student, it is noted that the student was not too familiar with discourse marker and had limited knowledge of it. This phenomenon was also figured out by Fung and Carter (2007), they came to a conclusion that the non-native students (Hong Kong) experienced such a limited corpus of discourse marker variety. In addition, Muller $(2004,2005)$ conducted comparative study of discourse markers employed by American and German students. Then, he found that the non-native student used less discourse marker than the native one. Further, in another research, Asik and Cephe (2013) also revealed that non-native student (Turkish) underwent less knowledge of it. It is found that both Asik and Cephe also investigated the senior undergraduate student just like what this current research did. There are also other 
researchers who found a similar phenomenon, they are Weinert (1998), Trillo (2002) and Hellerman and Vergun (2007).

Going with the point above, this current research thus suggested the lecturer to take attention and put it as a point in the scoring system. It will be better as well to make discourse marker a point of presentation review. It is in order to make the students get attention and familiar with discourse marker and its varieties. Well knowing and understanding it, the student can likely deliver a presentation better and more cohesive and coherent. Muller $(2004,2004)$ also argues so, he grants that if students know it adequately and use it effectively in spoken discourse, the points discussed will be easily gained by the audience (the receiver). Accordingly, Fung and Carter (2007) state that learning discourse markers facilitates students to get more successful overall language use and concern a well-constructed discourse. Further, in the following years, Lam (2009) posits that discourse marker is important for students to communicate pragmatically and get comprehensible interaction. Lam also notes that through discourse marker nonnative students can gain nativeness in the spoken and written discourse of English. This argumentation is in line with Halliday and Hasan (1976) who posit that discourse marker may help people to create natural text (spoken and written) which gain a higher level of coherence.

Dealing with learning process, Asik and Cephe (2013) specifically argue that Turkish non-native students may have a fluent spoken discourse, if they have adequate insight of discourse marker and tend to use it and they need to be supported by teacher through class interaction. Thus, this point is in line with what this current research suggested to the lecturer. Furthermore, discourse markers can be taught by both explicit and implicit teaching (Rose \& Kasper, 2001; McCarthy \& Carter, 1998). Therefore, it can be argued that going along with discourse markers may help students to get coherent discourse and deliver a discussion which is understandable for the hearer.

\section{CONCLUSION}

It can be reported that both textual and interpersonal functions were found. Textual functions were used by speaker in order to link the discourse, structure meaning as text, create a cohesive passage of discourse, and to make the language relevant to the context, so that the sentences will look more organized and easy to understand. Further, all divisions of textual function were found as well, they are opening frame marker, closing frame marker, turn-taker, filler, topic switch, information indicator, sequence marker, and repair markers. The findings show that sequence marker is most frequently used. Each of function is presented below followed by the markers found. Sequence markers (and then, and, and the next, after that, and also) occurred for 53 times employed to indicate the continuity of information. The second one is filler ( $u ; m, e$ ), it was used to hold the floor and to fill an empty between two ideas happening 43 times. The next one is information indicator (the first, the first one, the second one, the third on, the last), they were found 28 times and used to initiate any entity mentioned as the point discussed; repair markers (it means that) were found 14 times and employed to repair the discourse and to make previous 
information clearer. Further, opening frame markers (Ladies and Gentlement, before we go further, and okay) were identified 13 times and used to open and to start a discourse. While closing frame markers (so, in conclusion) were found 10 times and employed to conclude and ended up the discussion. There is another closing marker found i.e. thank you very much for your attention, it was not only used to thank audiences, but also to close a spoken discourse. Further, topic switch marker (and then) was also found 9 times, and the least is turn taker only occurred once. In contrary, interpersonal function seldom occurred. It just occurred for 7 times. It is because speaker only focused on giving the explanation. There are 4 markers which indicated audience's and speaker's response, they are okay, yes, and just it. Then, 3 other markers are used by speaker to check the audiences' understanding and asking the agreement from the audiences toward the topic given. Further, this study also reported that one discourse marker has more than one functions. It depends on what condition and context of the sentence that speaker uttered.

On the other hand, this study came to another conclusion as well that sometimes the speaker seemed like being confused in applying the discourse markers in the presentation. As the result, the speaker often used the same discourse markers to connect clauses or sentences or even to indicate something in the discourse. Consequently, it influenced the way the speaker delivered the presentation and it made the presentation monotonous. Thus, this study also suggested to the lecture to be more aware toward the discourse markers uttered by student and consider it as the crucial part in delivering the presentation in the class. The lecturer also needs to discuss it intensively and then put it as an element of scoring system.

\section{ACKNOWLEDGEMENT}

Special thanks to Miss Ely Nurmaily for recommending the student and giving time to do video-recording in her class. This video really means to this research.

\section{REFERENCES}

Aijmer, Karin (1996). Conversational Routines in English. Convention and Creativity. London: Longman.

Aijmer, Karin (2002). English Discourse Particles. Evidence from a Corpus [Studies in Corpus Linguistics]. Amsterdam: John Benjamins.

Alami, Mazineh. (2015). Pragmatic Function of Discourse Markers: A Review of Related Literature. International Journal on Studies in English language and Literature (IJSELL) vol. 3.

Asik, Asuman and Cephe, Pasa Tevfik. (2013). Discourse Markers and Spoken English: Nonnative Use in the Turkish EFL Setting. English Language Teaching, Vol. 6, No. 12. 2013.

Asik, Asuman and Cephe, Brinton, L. (1996). Pragmatic Markers in English: Grammaticalization and Discourse Functions. Berling and New York: Mouto de Gruyter.

Castro, Claudia Marcela Chapetón. (2009). The Use and Functions of Discourse Markers in EFL Classroom Interaction. Profile, No. 11, Bogota Jan/Apr, 2009. Chaudron, C. \& J.C. Richards. (1986). The Effect of Discourse Markers on the Comprehension of Presentation s. Applied Linguistics 7/2: 133-127. 
Croker, Robert A. (2009). An Introduction to Qualitative Research. Heigham, Juanita \& Croker, Robert A. (eds.) in Qualitative Research in Applied Linguistics: A Practical Introduction. London: Palgrave Mcmillan.

Fortune, Begona Belles. (2006). Discourse Markers within the University Presentation Genre: A Contrastive study between Spanish and North-American Presentation. Humanities and Social Sciences Faculty: Universitat Jaume.

Fraser, B. (1996). Pragmatic Markers. Pragmatics. 6(2), 167-190.

Fung, L., \& Carter, R. (2007). Discourse Markers and Spoken English: Native and Learner Use in Pedagogic Settings. Applied Linguistics, 28(3), 410439.

Halliday, M. A. K., \& Hasan, R. (1976). Cohesion in English. London: Longman.

Hellermann, J., \& Vergun, A. (2007). Language which is not taught: The Discourse Marker Use of Beginning Adult Learners of English. Journal of Pragmatics, 39(1), 157-179.

Ismail, Hind M. (2014). Discourse Markers in Political Speeches: Forms and Functions. JJ. of College of Education for Women, University of Anbar Vol 23.

Jonsson, Helena. (2013). The Use of the Discourse Markers Kind of and Sort of in London Teenage Conversation. LUND University.

Jucker, Andreas H. and Yael Ziv. (1998). Discourse markers: introduction. Discourse markers: descriptions and theory. Philadelphia: Benjamins.

Lam, P. W. Y. (2009). Discourse Particles in Corpus Data and Textbooks: the Case of Well. Applied Linguistics, 31(2), 260-281.
Litosseliti, lia. (2010). Research Methods in Linguistics. Continuum International Publishing Group, London, United Kingdom.

McCarthy, M., \& Carter, R. (1998). Spoken grammar: What is it and how can we teach it? English Language Teaching Journal, 49(3), 207-218.

Meyerhoff, Miriam. (2012). Discourse Analysis. London: An Imprint of Bloomsburry Publishing Plc.

Müller, Simone. (2004). Well You Know That Type of Person: Functions of Well in the Speech of American and German Students. Journal of Pragmatics, 36(1), 1157-1182.

Muller, Simone. (2005). Discourse Markers in Native and Non-native English discourse. John Benjamin's publishing company, Amsterdam/Philadelphia.

Muti'ah, Zahra. (2015). Gender and Discourse a Study of Teacher Discourse in EFL Classroom. STBA Teknokrat, Lampung.

Nejadansari, Darius and Muhammadi Ali Mohammad. (2015). The Frequencies and Functions of Discourse Markers in the Iranian University EFL Classroom Disocurse. International Journal of Research Studies in Language Learning Vol. 4.

Ogoanah, Felix Nwabeze and Dele Samuael Adeyanju. (2013). The Contextual Implications of "Like" and "As In" as Pragmatic Markers in Nigerian English Usage. Journal of the Nigeria English Studies Association (JNESA) 16:1.

Rido, Akhyar. (2010). The Use of Discourse Markers as an Interactive Feature in Science Presentation Discourse in L2 Setting. TEFLIN Journal, Volume 21, Number 1.

Rose, K. R., \& Kasper, G. (Eds.) (2001). Pragmatics and Language Teaching. Cam- 
bridge, NY: Cambridge University Press.

Sharndama, Emmanuel C. and Samaila Yakubu. (2013). An Analysis of Discourse Markers in Academic Report Writing Pedagogical Implications. Department of English and Literary Study, Taraba State of Nigeria.

Schiffrin, D. (1987). Discourse Markers. Cambridge: Cambridge University Press. Swan, Michael. (2005). Practical English
Usage. Oxford: Oxford University Press. Trillo, J. R. (2002). The pragmatic fossilization of discourse markers in nonnative speakers of English. Journal of Pragmatics, 34(6), 769-784.

Weinert, R. (1998). Discourse organisation in the spoken language of L2 learners of German. Linguistische Berichte, 176, 459-488.

William, Nicholas. (2011). Research Methods the Basic. New York:Routledge.

\begin{tabular}{|c|c|c|}
\hline Lines & Participants & Utterances \\
\hline 1 & $\mathrm{~S}$ & Assalamualaikum warohmatullahi wabarohaktu/ \\
\hline 2 & $\mathrm{~A}$ & Waalikumsalam warohmatullahi wabarokatu/ \\
\hline 3 & $\mathrm{~S}$ & Okay $\downarrow$. Before we go further about. u:m my book \\
\hline 4 & & report, entitled the authentic story of pinocchio of \\
\hline 5 & & tuscany by Carlo Collo- +Collodi, maybe I wanna ask \\
\hline 6 & & one of you. Maybe miss Dena.. u:m. \\
\hline 7 & $\mathrm{~S}$ & what is the first thing, that come to your mind, about \\
\hline 8 & & Pinocchio? \\
\hline 9 & A & //yes// \\
\hline 10 & & nose \\
\hline 11 & $\mathrm{~S}$ & nose? Just it? \\
\hline 12 & $\mathrm{~A}$ & $(($ no) $)$ lie \\
\hline 13 & $\mathrm{~S}$ & //okay// \\
\hline 14 & $\mathrm{~S}$ & okay, u:m. \\
\hline 15 & & actually $\uparrow$, all of you. us u:m know about Pinocchio’s \\
\hline 16 & & story, right? \\
\hline 17 & A & //yes// \\
\hline $\begin{array}{l}18 \\
19\end{array}$ & $\mathrm{~S}$ & $\begin{array}{l}\text { It is tell us about not tell lie, and then about } \mathbf{u}: \mathbf{m} \text {. gifeto, } \\
\text { and then blufery and others/ }\end{array}$ \\
\hline 20 & $\mathrm{~S}$ & so ladies and gentlemen, in THIS quotation, we -- we \\
\hline 21 & & know that the implicit meaning about -- about the \\
\hline 22 & & quotation itself/ it means that, u:m from. one \\
\hline 23 & & generation to other --another generation, the Pinocchio \\
\hline 24 & & story, always give the good moral message for -- \\
\hline 25 & & especially for children, about do not tell lie, \\
\hline 26 & & and then do not trust with stranger easily, \\
\hline 27 & & and others/ \\
\hline
\end{tabular}




\begin{tabular}{|c|c|c|}
\hline Lines & Participants & Utterances \\
\hline 28 & \multirow{5}{*}{$\mathrm{S}$} & So, in this Pinocchio story itself, we know that.. u:m \\
\hline 29 & & Pinocchio is just like e -- just like -- just like puppet, and \\
\hline 30 & & then, become the real $\uparrow$ boy/ it means that, u:m this -- \\
\hline 31 & & this teach to all - to all children that, nothing is \\
\hline 32 & & impossible/ \\
\hline 33 & \multirow[t]{4}{*}{$\mathrm{S}$} & So, pino that - we believe that, there is no. $\mathbf{u}: \mathbf{m}$. there \\
\hline 34 & & there is no -- ((what)) -- there is no someone that, $\mathbf{u}: \mathbf{m}$ \\
\hline 35 & & you can know from Pinocchio story, there are so many \\
\hline 36 & & kinds of moral message in- +inside it/ \\
\hline 37 & \multirow[t]{5}{*}{$\mathrm{S}$} & Okay, about the urgency $\uparrow$ of this fiction book, \\
\hline 38 & & Pinocchio is know ((as)) far and wide as the puppet who \\
\hline 39 & & strived, to become a boy, who learned to live $\uparrow$, to the \\
\hline 40 & & qualities required of the -- of a real boy, to be brave $\uparrow$, \\
\hline 41 & & truthful $\downarrow$, don't tell lie, and unselfish/ \\
\hline 42 & \multirow[t]{5}{*}{$\mathrm{S}$} & So, in this book $\uparrow$, e:m there are so many kinds of moral \\
\hline 43 & & message, especially for children that. so after read book, \\
\hline 44 & & perhaps that children can $\mathbf{u}: \mathbf{m} .$. APPLY $\uparrow$ the good \\
\hline 45 & & behavior, especially do not tell lie with our parents $\downarrow$, \\
\hline 46 & & with the society, and etcetera/ \\
\hline 47 & \multirow[t]{6}{*}{$\mathrm{S}$} & Okay, about the biographical of sketch, especially u:m -- \\
\hline 48 & & every single book have their own author, so. the book of \\
\hline 49 & & the authentic story of Pinocchio of Tuscany, $\mathbf{u}: \mathbf{m}$ the \\
\hline 50 & & author Carlo lorenzini was born in Florence, Italy on no- \\
\hline 51 & & + November twenty four, eighteen twenty six/ \\
\hline 52 & & \\
\hline 53 & \multirow[t]{12}{*}{$\mathrm{S}$} & He later $\uparrow$ adopter the pseudonym, "Carlo Collodi", so it \\
\hline 54 & & means that, the name of Carlo -- Carlo Lorenzini \\
\hline 55 & & change to Carlo Collodi, borrowing his u:m nom de \\
\hline 56 & & plum from the village of collodi. So, they - he changes \\
\hline 57 & & his name from Calro Lorenzini to Carlo Collodi, \\
\hline 58 & & following the name of the village, in their town/ \\
\hline 59 & & And also Collodi was the eldest - the eldest of ten \\
\hline 60 & & children, though seven of his. sibling, died very early in \\
\hline 61 & & life, his parents, Dominico -- Domini- +Dominico \\
\hline 62 & & Lorenzini and Angelica Orzani, were \\
\hline 63 & & domestic servants to \\
\hline 64 & & Marquis Lorenzo Ginori lisci/ \\
\hline
\end{tabular}




\begin{tabular}{|c|c|c|}
\hline Lines & Participants & Utterances \\
\hline 65 & \multirow[t]{10}{*}{$\mathrm{S}$} & okay $\uparrow$, and the next $(())$ physical description in this -- in \\
\hline 66 & & this book, the author of this book is Carlo Collodi, and \\
\hline 67 & & then the title is the authentic story of Pinocchio of \\
\hline 68 & & Tuscany $\uparrow$. and then the year two thousand, publisher \\
\hline 69 & & Jerry Cross and Pauline Bondonno Cross, Italy. \\
\hline 70 & & And then this book contains of one hundred forty three \\
\hline 71 & & pages, and the genre is fantasy, \\
\hline 72 & & because $\mathbf{u}: \mathbf{m}$ the writer - after the - af- + after read this \\
\hline 73 & & book, especially. \\
\hline 74 & & Pinocchio itself is fantasy \\
\hline 75 & \multirow[t]{29}{*}{$\mathrm{S}$} & Okay, $\{\mathrm{NS}\}$ e:m the strength of this book, especially \\
\hline 76 & & after the writer -- read this book, the first one $\uparrow$ is $\downarrow$ the \\
\hline 77 & & title of this book. is simple and interesting/ \\
\hline 78 & & It means that, e:m when the chil $\uparrow$ dren $\downarrow$ or $\mathbf{u}: \mathbf{m}$. adult \\
\hline 79 & & people and etcetera/ \\
\hline 80 & & They can also understand, the meaning of the authentic \\
\hline 81 & & of Pinocchio/ \\
\hline 82 & & So it means that Pinocchio is, a really famous story, $\mathbf{u}: \mathbf{m}$ \\
\hline 83 & & in -- in our era, and then second one, is the cover is \\
\hline 84 & & colorful and attract people to read this book $\uparrow$, especially \\
\hline 85 & & for children, and the third one is, this book so good to be \\
\hline 86 & & read, u:m especially for children, because. there are -- \\
\hline 87 & & there are some moral message inside this -- inside the \\
\hline 88 & & story, and fourth is, this book is using simple -- simple \\
\hline 89 & & language style, because COMMONLY, the u:m. \\
\hline 90 & & children, read - read this book, because the. language \\
\hline 91 & & u:m.. really simple/ so, children or adult people can \\
\hline 92 & & read this book, understand -- can understand what is the. \\
\hline 93 & & story inside this book/ \\
\hline 94 & & And then, communicative and easy to understand, so \\
\hline 95 & & the reader able to construct the meaning easily/ and the \\
\hline 96 & & last is, there are some pictures. inside $\mathbf{u}: \mathbf{m}$ the story, so \\
\hline 97 & & the reader can understand that. \\
\hline 98 & & what the story talking about, \\
\hline 99 & & and then setting, \\
\hline 100 & & there are some picture $\{\mathrm{NS}\}$ of Pinocchio and then \\
\hline 101 & & Geffeto, $\{\mathrm{NS}\}$ some character in the story of Pinocchio \\
\hline 102 & & $\{\mathrm{NS}\}$. book $\downarrow$ \\
\hline 103 & & \\
\hline
\end{tabular}

Fungsi Pemarkah Wacana: Sebuah Kasus di Kelas Berbicara pada Level Universitas 


\begin{tabular}{|c|c|c|}
\hline Lines & Participants & Utterances \\
\hline 104 & \multirow[t]{28}{*}{ S } & Okay, e:m about $\{\mathrm{NS}\}$ e:m extrinsic element in this \\
\hline 105 & & Pinocchio -- Pinocchio book, the theme is - e: the \\
\hline 106 & & theme of the story about end lasting love/ \\
\hline 107 & & Why I choose. the theme is end lasting love, because I \\
\hline 108 & & don't choose. do not tell lie, and then e:m do not trust \\
\hline 109 & & to stranger easily $\{\mathrm{NS}\}$, because I think that.. \\
\hline 110 & & everlasting love is the story, when gepetto really love \\
\hline 111 & & pinocchio, and the lasting love. u:m even Pinocchio tell \\
\hline 112 & & lie, and then even Pinocchio become naughty boy, so \\
\hline 113 & & Gepetto really love. and always take of -- take of him/ \\
\hline 114 & & So I choose that the theme is everlasting love, become, \\
\hline 115 & & the theme of this story/ \\
\hline 116 & & and then, about the character and characterization, the \\
\hline 117 & & first one is, major character/ \\
\hline 118 & & The first $\uparrow$ protagonist character is Pinocchio. So, why.. \\
\hline 119 & & pinocchio become the the major protagonist character, \\
\hline 120 & & because u:m Pinocchio $\uparrow$ as the main character, in all of \\
\hline 121 & & -- all of the story, or the sub - the subtitle in the story \\
\hline 122 & & itself/ \\
\hline 123 & & So, I believe that, Pinocchio hav- + have protagonist \\
\hline 124 & & character, and it can be seen, from the $\{C G\}-$ \\
\hline 125 & & it can be seen from the, quotation inside the story, "but I \\
\hline 126 & & am different from the other boys! I am -- the best boy in \\
\hline 127 & & the world, and I $\uparrow$ always tell the truth/ \\
\hline 128 & & I promise you, papa $\uparrow$. I will be - \\
\hline 129 & & I will be very nice to you and \\
\hline 130 & & I will take good care of you"/ \\
\hline 131 & & \\
\hline 132 & \multirow[t]{5}{*}{ S } & And then about the second protagonist character, \\
\hline 133 & & I choose.. Gepetto. as the second protagonist character, \\
\hline 134 & & because u:m. Gepetto $\uparrow$ as the creator of Pinocchio \\
\hline 135 & & itself, as the father of -- of the Pinocchio itself/ \\
\hline 136 & & \\
\hline 137 & \multirow[t]{8}{*}{ S } & We can -- we can know from the quotation itself, that \\
\hline 138 & & Pinocchio really want to buy $\mathrm{ABC}$ book, but gepetto \\
\hline 139 & & does not have. u:m money $\uparrow$-- does not have money. and \\
\hline 140 & & after that Gepetto sells. his jacket, and then just \\
\hline 141 & & wearing shirt and trousers to buy ABC book's $(())$ to \\
\hline 142 & & Pinocchio itself/ \\
\hline 143 & & So, I choose. Gepetto as the second protagonist \\
\hline 144 & & character, inside the story/ \\
\hline
\end{tabular}




\begin{tabular}{|c|c|c|}
\hline Lines & Participants & Utterances \\
\hline 145 & \multirow[t]{10}{*}{ S } & And then the second one is, major antagonist. \\
\hline 146 & & character, the fox and the cat, are ((available)) in the \\
\hline 147 & & film, because e:m there are some additional $\{\mathrm{NS}\}$ \\
\hline 148 & & character inside the story of Pinocchio $\{$ NS $\}$, just like, \\
\hline 149 & & the fox and the cat. Because, the fox and the cat $\mathbf{u}: \mathbf{m}$. \\
\hline 150 & & always e tell -- tell lies, with Pinocchio and also $(())$ \\
\hline 151 & & want to, $\mathbf{u}: \mathbf{m} . .$. always.. make $\uparrow$. his way to pleasure \\
\hline 152 & & island/ it means that, e:m always having e:m bad \\
\hline 153 & & planning to Pinocchio, just like e wanna kill Pinocchio, \\
\hline 154 & & and etcetera/ \\
\hline 155 & \multirow[t]{14}{*}{ S } & Okay, about the plot, especially, ladies and gentlemen, \\
\hline 156 & & in this. Story have u:m.. plot/ \\
\hline 157 & & The first one is introduction, $\mathbf{u}: \mathbf{m}$ the story was begin \\
\hline 158 & & when mister Cherry the carpenter found a piece of \\
\hline 159 & & woods, that laughed and cried like a child, when he \\
\hline 160 & & picked up. his ax to cut, $\{\mathrm{NS}\}$ the bark of the log, he \\
\hline 161 & & heard a tiny -- tiny voice whimpering. "don't hit me \\
\hline 162 & & hard!" and also, it means that, we can see from the. \\
\hline 163 & & quotation inside the story, "don't hit me hard!", it \\
\hline 164 & & means that, $\mathbf{u}: \mathbf{m} .$. the introduction or the -- the first \\
\hline 165 & & story, appear when mister Cherry e find e such kind of. \\
\hline 166 & & Piece of wood $\uparrow /$ \\
\hline 167 & & so the writer. believe that, it is $\uparrow$ as the introduction of \\
\hline 168 & & the story $\downarrow /$ \\
\hline 169 & \multirow[t]{13}{*}{ S } & and then the second one is about the climax/ \\
\hline 170 & & the climax, starts, when mister Cherry give \\
\hline 171 & & the wood that can make a tiny voice to the -- the \\
\hline 172 & & Gepetto $\downarrow /$ \\
\hline 173 & & so it is e:m. As the begi- +begining of the problem, or \\
\hline 174 & & we ((say)) as the. climax where. Mister Cherry afraid, e: \\
\hline 175 & & there is s- +sound of the wood/mister Cherry, gave to.. \\
\hline 176 & & the Gepetto, and after that, think about, he wants make \\
\hline 177 & & puppet/ \\
\hline 178 & & so it means that, e: the climax of this -- of this story, \\
\hline 179 & & when Gepetto makes the puppet, \\
\hline 180 & & and after that um gepetto gave the name \\
\hline 181 & & of the wood itself, as u:m Pinocchio/ \\
\hline
\end{tabular}




\begin{tabular}{|c|c|c|}
\hline Lines & Participants & Utterances \\
\hline 182 & \multirow[t]{12}{*}{ S } & Okay, the top of con- + conflict/ \\
\hline 183 & & The top of conflict start when.. pinocchio tells. lie to the \\
\hline 184 & & gepetto/ so, there are so many kind of problem. \\
\hline 185 & & Happen in Pinocchio, because they -- he always tells lie \\
\hline 186 & & with. Gepetto just like. It can be seen from the \\
\hline 187 & & quotation, "and the Pinocchio sold. $\mathrm{ABC}$ book to him. \\
\hline 188 & & right then and there"/ \\
\hline 189 & & So, after Gepetto sell it $\{\mathrm{NS}\}$ to another people/ \\
\hline 190 & & it means that $\{\mathrm{NS}\}$ there are such top of con- + conflict \\
\hline 191 & & or the $\mathbf{u}: \mathbf{m} .$. the high problem that happen in the -- in \\
\hline 192 & & the story when gepetto. sold. $\mathrm{ABC}$ book to another \\
\hline 193 & & people/ \\
\hline 194 & \multirow[t]{13}{*}{ S } & About the resolution. Pinocchio feels that, after he tells \\
\hline 195 & & lie. $\mathbf{u}: \mathbf{m}$ again and again, and then he thinks that, no \\
\hline 196 & & one $\uparrow$ can help him -- ask -- ask him sorry to the gepetto, \\
\hline 197 & & about -- about about his -- e -- his mistake, and also hug \\
\hline 198 & & Gepetto. He was. When he found, a ((minutelatery)) \\
\hline 199 & & that he was no longer a woo- +woo $\uparrow$ den puppet, he had \\
\hline 200 & & become a boy, like all the other/ \\
\hline 201 & & So, we see from the quotation, $\mathbf{u}: \mathbf{m} .$. the resolution is, \\
\hline 202 & & when. pinocchio asking sorry to the gepetto, and after \\
\hline 203 & & that.. they -- he changes become a real boy/ So \\
\hline 204 & & pinocchio, does not -- does not um.. couldn't be. e: \\
\hline 205 & & puppet anymore/ \\
\hline 206 & & \\
\hline 207 & \multirow[t]{16}{*}{ S } & Okay, about the. setting inside. the Pinocchio story \\
\hline 208 & & itself/ \\
\hline 209 & & The setting of place, took in gepetto's home, forest, \\
\hline 210 & & puppet theatre, blue fairy house/ \\
\hline 211 & & and then the setting of the time Pinocchio story, in the \\
\hline 212 & & golden ERA of Disney film, is consi- +considered \\
\hline 213 & & nineteen thirty seven until nineteen fourty two/ \\
\hline 214 & & It means that, when the.. Pinocchio story e: establish in \\
\hline 215 & & the era that literature, first establish and their \\
\hline 216 & & imagination/ \\
\hline 217 & & So it means that, the golden era, in -- in that era, the \\
\hline 218 & & literature especially children literature, like -- just like \\
\hline 219 & & fairy tale, and the $\mathbf{e}$ the imagination. \\
\hline 220 & & So, setting of circumstance $\uparrow$. \\
\hline 221 & & In this story, talking about, the common society in \\
\hline 222 & & the real life/ \\
\hline
\end{tabular}




\begin{tabular}{|c|c|c|}
\hline Lines & Participants & Utterances \\
\hline 223 & \multirow[t]{8}{*}{ S } & About the moral message, the writer found. Three of \\
\hline 224 & & moral messages, the first one is, do not tells lie to \\
\hline 225 & & everyone, especially our parent/ \\
\hline 226 & & And the second one is, do not trust -- do not trust with \\
\hline 227 & & the strangers easily/ \\
\hline 228 & & And the third one is, it is really IMPORTANT. no one \\
\hline 229 & & GIVE everlasting love, except our parent/ \\
\hline 230 & & So it make so important $\downarrow /$ \\
\hline 231 & \multirow[t]{17}{*}{ S } & and then about $\{N S\}\{L G\}$ e: the $\{N S\} \ldots$. . $C G\}$ so the \\
\hline 232 & & point of view, u:m the moral value that used. by the \\
\hline 233 & & author, is omniscient point of view/ \\
\hline 234 & & so it means that, omniscient is the.. e: which is based \\
\hline 235 & & on.. borough two thousand and seven, "omniscient \\
\hline 236 & & point of view is the author. knows $\uparrow$ everything about \\
\hline 237 & & the character and the author narrator tells the story $\downarrow$ / \\
\hline 238 & & so it can make children feel confuse, just like. Pinocchio. \\
\hline 239 & & in blue fery house, and after that in Gepetto's house, \\
\hline 240 & & and after that in the sea, \\
\hline 241 & & and after that/ \\
\hline 242 & & so $\left(\left({ }^{*}\right.\right.$ apa $\left.)\right)\{\mathrm{NS}\}$ it can makes -- it can makes the \\
\hline 243 & & children feel confuse/ \\
\hline 245 & & so, especially where the - \\
\hline 246 & & u:m where Gepetto's house, where Pinocchio's exactly. \\
\hline 247 & & House/ \\
\hline 248 & & \\
\hline 249 & \multirow[t]{10}{*}{ S } & In conclusion, Pinocchio was one of fiction story, \\
\hline 250 & & which WRITTEN with the purpose or \\
\hline 251 & & sociali- socialai- +socializing children to meet $\{\mathrm{NS}\}$ \\
\hline 252 & & definite normative, expectation at home \\
\hline 253 & & and in the society/ \\
\hline 254 & & So moral - moral lesson, we can get from Pinocchio \\
\hline 255 & & story, do not tell lie, \\
\hline 256 & & and about the lasting love, $\{$ NS $\}$ because it is $-\mathbf{u}: \mathbf{m}$-- \\
\hline 257 & & do not to lie, it is. not good, and it will only lead you to \\
\hline 258 & & some serious problem/ \\
\hline 259 & \multirow[t]{5}{*}{ S } & So, I have. one quotation from Pinocchio, "a lie keeps \\
\hline 260 & & GROWING AND GROWING, until. it is $\uparrow$ as PLAIN. \\
\hline 261 & & as the NOSE. on your FACE/ \\
\hline 262 & & Thank you very much for your nice attention, \\
\hline 263 & & wasalamualaikum warohmatullahi wabarokatu/ \\
\hline
\end{tabular}

Fungsi Pemarkah Wacana: Sebuah Kasus di Kelas Berbicara pada Level Universitas 